\title{
ROLA BADAŃ BUDOWY
} TECHNICZNEJ I ROZPOZNANIA WARSZTATU ARTYSTY NA PRZYKŁADZIE TWÓRCZOŚCI MELI MUTER

\author{
Katarzyna A. CYBULSKA (Toruń)
}

Mimo iż informacje o budowie obrazu nie zawsze mają bezpośredni wpływ na interpretacje o charakterze humanistycznym, to jednak mają zasadnicze znaczenie dla wyjaśnienia, jakimi środkami osiągnięto konkretny wyraz artystyczny dzieła, pozwalają ponadto zrozumieć, w jaki sposób poszczególne elementy, niekiedy wydawałoby się mało istotne, współtworzą jego skomplikowaną strukturę, oraz jaki proces technologiczny temu towarzyszy ${ }^{2}$.

Wybór rodzaju użytych przez artystę podobrazi: płóciennego (a co za tym idzie rodzaju i splotu płótna), metalowego, tektury, sklejki czy deski i ich przygotowanie, a także charakter zaprawy lub jej brak, oraz wybór spoiwa, pigmentów, tworzyw i dodatkowych elementów (szczególnie istotny w sztuce nowoczesnej), mają znaczenie w budowaniu nie tylko formy, ale także w przekazie samej treści dzieła, wpływając zasadniczo na jego odbiór, jego wartości artystyczne, estetyczne, na jego ogólny charakter. Ponadto ułatwiają i pozwalają na wyodrębnienie poszczególnych etapów twórczych, a więc i określenie charakterystycznego dla każdego malarza sposobu myślenia artystycznego. Rejestrują jego zmagania się z materią, w której pracuje, poszukiwania właściwych środków wyrazu, sposobu przekazania własnej wizji. A co także bardzo istotne pomagają ponadto ocenić jego umiejętności techniczne. Dzięki badaniom bu-

\footnotetext{
${ }^{1}$ Kolekcja Liny i Bolesława Nawrockich, M. Muter, „Guide de la Peinture”, [b.d.], rkp., s. 19.

${ }^{2}$ G. Bastek, G. Janczarski, Dlaczego malarstwo weneckie, [w:] Serenissima - światto Wenecji: dzieła mistrzów weneckich XIV-XVIII wieku ze zbiorów Muzeum Narodowego w Warszawie $w$ świetle nowych badań technologicznych, historycznych i prac konserwatorskich, [oprac. i red. kat. G. Bastek, G. Janczarski, A. Ziemba]. Muzeum Narodowe w Warszawie, Warszawa 1999, s. 49.
} 
dowy technicznej staje się jasne, co naprawdę kształtuje owe subtelności stylu danego artysty i decyduje o ostatecznym wyrazie obrazu.

Badania budowy technicznej dzieł sztuki mają za zadanie odpowiedzieć na podstawowe pytania: jakie materiały zostały użyte do powstania konkretnego obiektu, jakiej były jakości, w jakiej ilości zostały wykorzystane oraz $\mathrm{w}$ jaki sposób. Z ilu warstw oryginalnych (technologicznych) zbudowane jest dane dzieło sztuki, jakiej grubości są te warstwy oraz jaki mają skład. Poza materiałami zastosowanymi w procesie tworzenia dzieła, badaniom podlegają również materiały dodane podczas konserwacji lub reperacji, tzw. elementy wtórne. Istotne jest określenie, jaki one mają wpływ na ostateczny odbiór dzieła, a na ile je zafałszowują czy przekłamują. Badaniom podlegają także zjawiska powstałe $\mathrm{w}$ wyniku naturalnego procesu starzenia się dzieła lub jego przyspieszonej degradacji, co pozwala na poznanie przyczyn i mechanizmów procesów niszczenia, tak by móc im skutecznie zapobiegać, powstrzymywać je i minimalizować ich skutki. Pozwalają ponadto zrozumieć zjawisko dobrego lub złego stanu zachowania obiektu, bez względu na jego wiek (oczywiście poza uszkodzeniami mechanicznymi), starając się ustalić jakie materiały czy technika przyczyniły się do tego, że konkretne dzieło jest np. tak wyjątkowe i dobrze zachowane lub co, niestety ma również miejsce, staje się z czasem coraz bardziej nieczytelne.

Badania analityczne pozwalają na wydobycie wiedzy bezpośrednio z samego dzieła, niekiedy także na weryfikację tekstów źródłowych, których studia, już od czasów starożytnych, poprzez średniowiecze i okres nowożytny, były i są nieocenioną skarbnicą wiedzy odnoszącą się do rozwoju technik malarskich.

Jak zauważa Zofia Kaszowska, tzw. badania podstawowe, których celem jest ,jedynie" identyfikacja materiałów, powinny być systematycznie kontynuowane. Mimo iż stan wiedzy o materiałach i technikach w różnych okresach, miejscach i warsztatach oraz artystach uległ znacznemu rozbudowaniu, to nie wszystko zostało dotąd należycie jeszcze rozpoznane i przestudiowane. Owa, pewnego rodzaju „baza danych”, jak ja określa badaczka, winna być stale poszerzana, tak by stanowiła wartościowy materiał odniesienia dla kolejnego pokolenia badaczy ${ }^{3}$.

W ostatnich latach obserwujemy bardzo szybki rozwój metod analitycznych oraz ich znaczne udoskonalenie ${ }^{4}$. Intensywnie stosuje się tzw. badania nieniszczące, które są

\footnotetext{
${ }^{3}$ Z. Kaszowska, Możliwości i ograniczenia metod analitycznych stosowanych w badaniach technologicznych gotyckich malowidet tablicowych, Studia i Materiały Wydziału Konserwacji i Restauracji Dzieł Sztuki Akademii Sztuk Pięknych w Krakowie, 2010 t. 19, s. 13.

${ }^{4}$ Wykonywane są standardowo badania podstawowe, polegające na ocenie wyglądu obrazu w świetle rozproszonym, skośnym i przechodzącym, rejestracji fluorescencji wywołanej promieniowaniem ultrafioletowym, rejestracji wyglądu malowidła w bliskiej podczerwieni, jak również rentgenografia, reflektografia w ultrafiolecie czy też reflektografia w zakresie bliskiej podczerwieni z selektywną rejestracją barw.

Identyfikuje się podobrazia, wypełniacze i pigmenty warstw malarskich oraz zapraw, a także ich spoiwa. Do najczęściej stosowanych w tym celu metod analitycznych należą: techniki mikroskopowe, mikrochemiczne, kroplowe (te należą także do mikrochemicznych), rentgenowska analiza fluorescencyjna (XRF), chromatografia gazowa (GC), spektroskopia w podczerwieni $\mathrm{z}$ transformacją Fouriera (FTIR) oraz chromatografia gazowa połączona ze spektrometrią masową (GC-MS). W celu określenia stratygrafii warstw wykonuje się przekroje poprzeczne próbek i poddaje badaniom mikroskopowym rejestrując między innymi ich wygląd $\mathrm{w}$ bliskiej podczerwieni w fałszywych barwach czy też fluorescencję w ultrafiolecie. Przekroje poprzeczne bada się także za pomocą energodyspersyjnej mikroanalizy rentgenowskiej z zastosowaniem mikroskopu elektronowego (SEM-EDS) oraz spektroskopii ramanowskiej (RS). Kiedy oglądamy układ warstw malarskich w przekroju stratygraficznym, widzimy i zaczynamy rozumieć w jaki sposób
} 
niezbędne w sytuacji, gdy z danego obszaru malowidła nie można pobrać próbek do badań, czy to ze względu na dobry stan zachowania warstwy malarskiej, oraz wysoką wartość artystyczną obrazu, czy też są uznane za niedopuszczalne ze względu na zasady etyki konserwatorskiej ${ }^{5}$.

Przykład wybitnej polskiej malarki, artystki École de Paris - Meli Muter ${ }^{6}$, oraz badania nad jej twórczością od strony technologii i techniki pozwalają przybliżyć i scharakteryzować jej warsztat malarski odsłaniając po części jego tajniki i możliwości, a tym samym wrażliwość malarską i geniusz artystki ${ }^{7}$ (il. 28).

Należy pamiętać, iż przez stulecia obrazy budowano logicznie, opierając się na gruntownej znajomości materiału i prawidłowym jego stosowaniu. W dawnych szkołach technika była ogniwem łańcucha tradycji, opartej na wiedzy i umiejętności zdobytej przez poprzedników, do której każdy mistrz dodawał coś własnego. Wiek XIX, a tym bardziej XX, w którym tworzyła Muter, były okresem zasadniczej zmiany, „Nową erą”, w której produkcją materiałów malarskich nie zajmowali się już sami artyści, a wyspecjalizowane manufaktury i firmy artystyczne, co oczywiście miało swój wpływ na brak bezpośredniej kontroli nad metodami, jakością i rodzajem materiałów używanych do produkcji farb, mediów, werniksów ${ }^{8}$ oraz przygotowaniem podobrazi ${ }^{9}$. To wszystko niewątpliwie przekładało się także na stan zachowania obrazów, ale również zmieniło samo podejście artystów do ich pracy, gdzie strona techniczna i tradycyjnie rozumiane rzemiosło malarskie zaczęły mieć znaczenie drugorzędne.

artysta uzyskiwał kolor i fakturę poszczególnych plam barwnych, jak budował swój obraz. Dostrzegamy zmiany optyczne pigmentów i spoiw, jak również warstwy wtórne, będące czy to przemalowaniem, czy ingerencją restauratorów. Ów przekrój jest poniekąd świadectwem historii obrazu, już sam w sobie jest dokumentem.

${ }^{5}$ Zob. m.in.: Scientific Examination for the Investigation of Paintings. A Handbook for Conservator - Restorers, eds. D. Pinna, M. Galeotti, R. Mazzeo, Firenze 2009; J. Rogóż, Zastosowanie technik nieniszczacych w badaniach konserwatorskich malowidet ściennych, Toruń 2009.

${ }^{6}$ Wł. Maria Melania Mutermilch (1876 Warszawa - 1967 Paryż), jedna z wielkich postaci kobiecych ówczesnego malarstwa i jedna z najwybitniejszych portrecistek swego czasu; por.: Mela Muter (1876-1967). Kolekcja Bolestawa i Liny Nawrockich, [katalog wystawy]. Muzeum Narodowe w Warszawie, grudzień 1994-luty 1995, oprac. B. Brus-Malinowska, B. Nawrocki, Warszawa 1994; J. Malinowski, B. Brus-Malinowska, W kregu École de Paris. Malarze żydowscy z Polski, Warszawa 2007; E. Bobrowska-Jakubowska, Artyści polscy we Francji w latach 1890-1918. Wspólnoty i indywidualności, Warszawa 2004; A. Wierzbicka, École de Paris. Pojęcie, środowisko, twórczość, Warszawa 2004; E. Bobrowska-Jakubowska, Portret „szalonych lat”: Mela Muter na międzynarodowej scenie artystycznej Paryża, [w:] Mela Muter. Malarstwo / Peinture, [red. M. A. Supruniuk, S. Majoch], Torun 2010.

${ }^{7}$ Dzieła Muter nie były do tej pory przedmiotem wnikliwych technologicznych i konserwatorskich analiz. Wszystkie analizowane obiekty należą do prywatnej kolekcji Liny i Bolesława Nawrockich, stanowiącej wystarczająco reprezentatywny materiał badawczy dla badań nad warsztatem artystki; K. A. Cybulska, Historia kolekcji: Mela Muter w zbiorach Bolestawa i Liny Nawrockich, [w:] Mela Muter. Malarstwo / Peinture, s. 41-46. Przedstawione w niniejszym artykule wyniki badań są częścią większego projektu, realizowanego przez autorkę w ramach pracy doktorskiej w Zakładzie Technologii i Technik Malarskich Instytutu Zabytkoznawstwa i Konserwatorstwa Uniwersytetu Mikołaja Kopernika w Toruniu.

${ }^{8}$ Wówczas kupowanych w tubach lub słoiczkach gotowych produktów.

${ }^{9}$ Podobrazia płócienne były wówczas dostępne w handlu już zazwyczaj zagruntowane, na krosnach lub cięte $\mathrm{z}$ wałka na metry. Podobnie podobrazia tekturowe. 
Mela Muter wypowiadała się w różnych technikach, tj. malarstwie olejnym, akwareli, rysunku, grafice, wykonywanych na różnych podłożach, papierowych, płóciennych, tekturowych, sklejce, które niejednokrotnie artystka wykorzystywała powtórnie, malując zarówno na awersach, jak i rewersach swoich podobrazi ${ }^{10}$. Mimo iż w zasadzie była samoukiem, miała świetnie opanowany warsztat akademicki, rysunek i samą technikę malowania. Potrafiła również bardzo szybko wypracować swój nader charakterystyczny sposób wypowiedzi artystycznej, gdzie strona techniczna dzieł miała kluczowe znaczenie $w$ ich odbiorze. Już w pierwszych recenzjach odnoszących się do twórczości Muter krytycy niejednokrotnie zwracali szczególną uwagę nie tylko na podejmowane przez artystkę tematy, ale na specyfikę jej warsztatu malarskiego, charakterystyczne środki wyrazu i technikę, w jakiej je osiąga.

Już w 1907 roku Tadeusz Jaroszyński na łamach „Tygodnika Ilustrowanego”, pisząc o indywidualnej wystawie Meli Muter w Warszawie, wskazywał na wzory, z których czerpie w swojej twórczości, wymieniając mistrzów: Gauguina, van Gogha, oraz polskich, Wyspiańskiego i Boznańską. Szczególnie podkreślał doskonałość warsztatową prac artystki, ich harmonię i ,skończoność”, wyrobienie zawodowe młodej malarki, którym nie ustępowała poziomowi swych inspiratorów ${ }^{11}$. Z kolei Wacław Gąsiorowski, wspominając o uczestnictwie Muter w Salonie paryskim, tego samego roku, pisał o jej interesującym, choć jednak według niego zmanierowanym sposobie malowania ${ }^{12}$.

W 1910 roku Henryk Zbierzchowski opublikował artykuł na temat dwóch artystek polskich, mieszkających i tworzących w Paryżu: Olgi Boznańskiej i Meli Muter właśnie. Odniósł się do różnorodności tematycznej, ale także technicznej dzieł Muter, skłaniając się jednocześnie do wniosków krytyki francuskiej zestawiającej jej twórczość z malarstwem van Gogha. Ponadto Zbierzchowski podkreślił wielką indywidualność, oryginalność oraz aktualność prac Muter, z ujawniającym się w nich silnym temperamentem twórczym, jednocześnie podkreślając, iż malarka nie identyfikuje się z żadną ze współczesnych szkół artystycznych ${ }^{13}$. Po wystawie w Barcelonie w Galerii Dalmau, w 1911 roku hiszpański krytyk Manuel Rodriguez Codolá zwrócił uwagę na różnorodność technik, jakimi się posługuje artystka, jak ją określił — eksperymentatorka. Zwrócił uwagę na rygorystyczną dyscyplinę jej przemyślanych kompozycji, wyzbytych przypadkowości, a obfitych w wyszukane środki ekspresji. Podkreślił, że już w pierwszych dziełach widoczny jest wyśmienity warsztat i silna osobowość artystki, a jej prace przedstawiają ogromną wartość artystyczną, treściową, a przede wszystkim techniczną $^{14}$. W 1923 roku, po trzeciej indywidualnej wystawie Muter w Warszawie, Władysław Skoczylas w recenzji z wystawy podkreślił otwartość Muter na nowe kierunki w sztuce, jej świadome liczne inspiracje, z zachowaniem jednakże własnej indywidualności twórczej, uznając za główne cechy charakteryzujące jej malarstwo monumentalizm i deformację. Zwrócił uwagę, iż kompozycje artystki mają cechy malarstwa współczesnego, a autorka stosuje w nich interesujące i nowatorskie

${ }^{10}$ Przykłady dwustronnie malowanych obrazów w twórczości artystki zostały omówione m.in. w artykule: J. Olszewska-Świetlik, K. A. Cybulska, Konserwator wobec autorskich zmian $w$ dzietach sztuki - zagadnienia etyczne i estetyczne na przyktadzie twórczości Meli Muter, [w:] Wokót zagadnień estetyki zabytku po konserwacji i restauracji, red. E. Szmit-Naud, B. J. Rouba, J. Arszyńska, Warszawa-Toruń, 2012, s. 229-246.

${ }^{11}$ T. J[aroszyński], Nowe talenty, Tygodnik Ilustrowany 1907 nr 43, s. 876.

${ }^{12}$ W. Gąsiorowski, Artyści polscy w Salonach paryskich, Świat 1907 nr 30, s. 4.

${ }^{13}$ H. Zbierzchowski, Z pracowni artystów polskich w Paryżu: Boznańska i Mutermilchowa, Tygodnik Ilustrowany $1910 \mathrm{nr}$ 40, s. 803-805.

${ }^{14}$ M. Rodriguez Codolá, Mela Mutermilch, Museum 1911 t. 1, s. 401-419. 
zabiegi techniczne ${ }^{15}$. Mieczysław Wallis natomiast w artykule z wystawy Muter w TZSP przypomniał jak wielką renomą cieszy się jej malarstwo na świecie. Zwrócił uwagę na oryginalną estetykę, prostotę i monumentalność jej kompozycji.

[...] Wybitnym rysem malarki jest dążenie do monumentalności. [...] Ambitnie zmierza ona do tego, co proste, wielkie i mocne. [...] Owo dążenie do monumentalności przejawia się w zamiłowaniu do wielkiego formatu obrazów (zwłaszcza portretów), w posługiwaniu się wielkimi liniami i wielkimi, niemal jednolitymi plamami barwnymi, w wysiłkach mających na celu osiągnięcie mocniejszej, spoistszej budowy obrazu. Jak dalece artystce zależy na dużych zwartych powierzchniach, o tym świadczy między innymi to, że w portretach z oczu zwykle zaznacza ona tylko brwi i powieki, mniemając, że dokładniejsze wykończenie oka, zwłaszcza zaś zaznaczenie tęczówki i źrenicy rozerwałoby całość twarzy $[\ldots]^{16}$.

Dostrzegając w jej pracach liczne inspiracje: pointylizmem — w punktowym sposobie malowania partii twarzy i rąk, malarstwem van Gogha — w żywej kolorystyce i ekspresyjnych pociągnięciach pędzla oraz Cézanne'a w konstruowaniu kompozycji obrazu, podkreślał jednocześnie, że była artystką niezależną, nienależącą do żadnej $\mathrm{z}$ grup artystycznych.

[...] Wszystkie utwory p. Muterowej odznaczają się wyrafinowanym kunsztem, świadomym swoich sposobów i środków, umiejącym korzystać mądrze ze zdobyczy poprzedników. Od pointylistów wzięła ona sposób kładzenia farb drobnemi kreskami, stosowany przez nią, zwłaszcza do malowania twarzy i rąk; od Van Gogha pochodzi także wyciąganie plam barwnych $\mathrm{w}$ pasma oraz łączenie tych pasm w fale, wiry i pęki. Wpływ Cézanne'a i jego szkoły ujawnia się najsilniej w krajobrazach dolin górskich i wybrzeży morskich o horyzoncie zamkniętym ze wszystkich stron górami lub zgoła bez horyzontu; w dążeniu do równowagi mas; w lekkiej stylizacji geometrycznej wzgórz, domów, drzew; w niezbyt ścisłem liczeniu się z prawidłami perspektywy ${ }^{17}$.

Wallis odniósł się również do stłumionego kolorytu prac malarki, widząc w tym techniczny świadomy zabieg, jak sądził uzyskany przez stosowanie przez nią, chropowatego niezagruntowanego płótna.

Barwy na obrazach p. Muterowej są zwykle matowe, stłumione, co pochodzi, jak się zdaje, z używanego przez malarkę — grubego i chropowatego — gatunku płótna, silnie wsysającego farbę. Paleta p. Muterowej składa się przeważnie z żółtej ochry, cynobru, seledynowej i oliwkowej zieleni, kobaltu, ultramaryny i fioletu. Niekiedy artystka pozwala płótnu przeświecać poprzez farbę; kiedy indziej znowu biel pozostawionego zupełnie bez zamalowania płótna służy jej jako czynnik kolorystyczny w sposób podobny, jak np. akwareliście biel papieru. [... $]^{18}$.

Dużo miejsca technicznej stronie prac artystki poświęcił także Jan Żyznowski, odrębność jej malarstwa widząc w stosowaniu świadomych niedopowiedzeń i w wyważonych tonacjach barwnych ${ }^{19}$. Również Jan Centnerszwer podkreślał zainteresowanie artystki różnymi technikami plastycznymi i doskonałe ich opanowanie, a co dość interesujące, świetlisty koloryt prac tłumaczył stosowaniem przez artystkę specjalnego

${ }^{15}$ W. Skoczylas, Z Zachęty Sztuk Pięknych: Wystawa prac Melanii Muter w TZSP, Tygodnik Ilustrowany $1923 \mathrm{nr} 15$, s. 234-235.

${ }^{16}$ M. Wallis, Kronika. Sztuki plastyczne, Przegląd Warszawski 1923 nr 25, s. 129-130.

${ }^{17}$ Tamże.

${ }^{18}$ Tamże.

${ }^{19}$ J. Żyznowski, Z Zachęty. Wystawa Meli Muter, Rzeczpospolita 1923 nr 86, s. 3. 
rodzaju płótna ${ }^{20}$. Robert Rey w uzyskaniu specyficznego nastroju prac widział stosowanie przez Muter odpowiednich zabiegów technicznych ${ }^{21}$. W 1927 roku w związku ze zorganizowaną w Galerii Josepha Billieta wystawą artystki, Rey napisał artykuł, którego znaczną część poświęcił właśnie analizie technicznej dzieł Muter. Zauważył, że technika pustych miejsc, stosowana przez artystkę, nie ma związków z dywizjonizmem Seurata, Signaca czy Grossa, a w niej właśnie upatrywał wielkość i oryginalność malarstwa Muter, jednocześnie zaznaczając, że swoje kompozycje konstruowała w oparciu o zasadę kontrastów.

To w 1913 zobaczyłem po raz pierwszy dzieła sygnowane Mela Muter. Jej technika wydawała mi się wtedy bardzo charakterystyczna. Pomiędzy jednym a drugim dotknięciem pędzla rozciągał się interwał, w którym płótno pozostawało nagie; ale mógłby zostać wypełniony jedynie nieuniknionymi wariacjami. Skoro tak, po co je wypełniać? [...]. Technika ta, trzeba stwierdzić, nie ma nic wspólnego z dywizjonizmem Seurata, Signaca czy też Grossa. Pozwala ona natomiast Meli Muter tworzyć obrazy niezwykle silne w wyrazie, skoro są na nich zaznaczone same, choćby tylko drobne akcenty... ${ }^{22}$.

Mieczysław Sterling pod koniec lat 20. XX wieku pisał o Muter jako o bezkompromisowej, kierującej się instynktem w malarstwie, doskonałej portrecistce:

Malarka ta nigdy nie szła na kompromisy. Nie szukała łatwej popularności, pozwalała wypowiadać się instynktowi z niepohamowaną swobodą. Jeżeli ulegała wpływom, to artystów najbardziej rewolucyjnych. Wpływy były przejściowe, wychodziła spod nich przewagą własnej indywidualności, na której zbudowała osobistą swoją formę ${ }^{23}$.

André Salmon zauważył, że artystka swoim stylem i podejmowaną w pracach problematyką, wykracza daleko poza sztukę akademicką, dając zapowiedź sztuki nowej, wolnej od skostnienia, niezależnej, broniącej indywidualności twórczej ${ }^{24}$. Paul Sentenac z kolei pisał:

[...] Mela Muter [...] przekłada swe artystyczne emocje na rzetelną materię, na farbę gęstą i szeroko nakładaną, na te jasne, złagodzone barwy zestawione zawsze z delikatną harmonią, które charakteryzują paletę tej artystki, rozpoznawalnej spomiędzy tysiąca innych ${ }^{25}$.

Również Jacques Millet pisał o fakturalnym potraktowaniu powierzchni płótna, w którym widział nawiązanie do van Gogha ${ }^{26}$.

Z przytoczonych wyżej fragmentów recenzji widać, iż stosowana przez Muter technika oraz materiały nie były niedostrzegane przez krytykę. Wręcz przeciwnie, jakże często widziano siłę sztuki Muter właśnie od strony jej techniki.

Śmiało możemy stwierdzić, że jej autorski warsztat i sposób pracy były wynikiem głębokich studiów i olbrzymiego doświadczenia. A techniczna strona pracy nie była obojętna artystce ani w jej twórczości, ani w ocenie przez nią twórczości jej kolegów.

${ }^{20}$ J. Centnerszwer, Z Zachęty. Wystawa Meli Muter, Nasz Przegląd 1923 nr 15, s. 3.

${ }^{21}$ R. Rey, Mela Muter, Der Cicerone 1926 nr 9, s. 286.

${ }^{22}$ Tenże, Mela Muter, Art et Décoration 1927, nr 303, s. 65.

${ }^{23}$ M. Sterling, Z paryskich pracowni. August Zamoyski - Mela Muter, Głos Prawdy 1929 nr 6, s. 3 .

${ }^{24}$ A. Salmon, Le peinture de Mela Muter, Pologne Littéraire $1933 \mathrm{nr}$ 87, s. 5.

25 P. Sentenac, Les expositions par Paul-Sentenac. Galerie de la Renaissance, La Renaissance 1930/6.

${ }^{26}$ J. Millet, Mela Muter à la Galerie Noseda [katalog wystawy], Avinion 1948. 
Ów świadomy według Muter brak dbałości o jakość stosowanych przez artystów materiałów, ich niewiedza oraz dyletantyzm, jak też nie zawsze uczciwe działania handlarzy materiałami malarskimi, nie były jej obojętne. Muter wielokrotnie wypowiadała się bardzo krytycznie, niekiedy wręcz pogardliwie, na temat nieświadomości artystów, o ich lekkomyślności i lenistwie, podkreślając iż taki stan rzeczy prowadzi nie tylko do upadku rzemiosła malarskiego, jak określała pracę malarzy, ale także do zupełnego niezrozumienia istoty malarstwa, nawet przez nich samych. W swoim dzienniku Muter pisze:

[...] Trzeba przyznać że my malarze pracujemy w bardzo delikatnej materii, najbardziej ze wszystkich... [...] Ze wszystkich starożytnych dzieł najmniej zachowało się właśnie malarstwo. Mamy greckie pomniki, rzeźbiarskie i architektoniczne, rzemiosło, gliniane wazy, grzebienie, klejnoty, meble. To wszystko zostało w większej liczbie niż dzieła malarskie. Więc z powodu kruchości malarstwa musimy otoczyć nasze dzieło większą troską jako malarze, większą niż inni artyści ${ }^{27}$.

Tylko malarz, sam swoją pracą i troską może zadbać by jego dzieło przetrwało, poznać dogłębnie technikę, którą się posługuję ${ }^{28}$.

I dalej:

[...] Widzimy dzisiaj jak malarze walczą z różnymi trudnościami w technice malarskiej. Widzimy że ich dzieła już za życia ich autorów niszczą się szybko: ciemnieją, żółkną, pokrywają się krakelurami. I widzimy jak nadchodzi godzina jak dzieło będzie nie do rozpoznania i może zniknąć całkiem. Nasze sumienie rzemieślnika budzi się i szukamy sposobów żeby chronić nasze obrazy przed tym niebezpieczeństwem. I to doprowadziło mnie, żeby przedsięwziąć poszukiwania w stronę dzieł dawnych mistrzów, które przetrwały, świeże, nietknięte przez wieki. Przeanalizować te, które przetrwały, na ścianie, na płótnie, na desce. Dawni malarze pokrywali ściany malowidłami nie tylko wzruszającymi, ale też trwałymi, o czym należy pamiętać. One przetrwały znaki czasu, nie poddały mu się $e^{29}$.

[...] w zgiełku nie mamy czasu na kontemplację i refleksję, nie sprawdzamy osobiście, tylko zostawiamy innym ten trud. I zostawiamy to pierwszemu lepszemu - komukolwiek $^{30}$.

Skupiając się tylko na wybranych zagadnieniach warsztatu Muter i jego ogólnej charakterystyce oraz prezentując tylko część przeprowadzonych badań budowy technicznej jej dzieł, jedynie je sygnalizując, wiemy że artystka bardzo chętnie wykorzystywała pod malarstwo olejne podobrazie płócienne, o różnym splocie i gęstości. Nieco rzadziej tekturę czy sklejkę. I tylko na początku twórczości malowała niekiedy na gotowych podobraziach fabrycznych, których później się nie spotyka w jej twórczości ${ }^{31}$. Przeważnie podobrazia przygotowywała sama. Artystka stosowała zawsze biały grunt, najczęściej kredowy i kazeinowy ${ }^{32}$, robiony własnoręcznie, naniesiony zazwyczaj

${ }^{27}$ M. Muter, ,Guide de la Peinture”, s. 1-2.

${ }^{28}$ Tamże, s. 19.

${ }^{29}$ Tamże, s. 1.

${ }^{30}$ M. Muter, En marge de ma Peinture, Les Cahiers de l'Etoile 1929 nr 7, s. 84.

${ }^{31}$ Przykładem może być obraz Melancholia - autoportret czy Autoportret w świetle księżyca.

${ }^{32} \mathrm{~W}$ znacznej liczbie obrazów w warstwie gruntu zidentyfikowano spoiwo kazeinowe z dodatkiem oleju lnianego, między innymi w Brzozach, Dziewczynce na krześle, Portrecie mężczyzny $w$ biatej tunice, Portrecie Anglika lub samo spoiwo kazeinowe, np. w Portrecie pani Lefebvre czy Autoportrecie w turbanie I. Badania fizykochemiczne wykazały, iż nie ma zależności pomiędzy użytym spoiwem a składem wypełniaczy. Niekiedy zaprawa jest na bazie gipsu i bieli 
mniej lub bardziej starannie w jednej warstwie. Jego faktura uzależniona jest od sposobu nałożenia zaprawy na powierzchnię podobrazia, a tym samym już na tym etapie odzwierciedla koncepcję artystki. Niekiedy była nakładana nożem lub szpachlą, innym razem za pomocą wałka nadając powierzchni ,gruzełkowatą” i chropowatą fakturę, która w sposób dość jednoznaczny sprawia, że mamy wrażenie jakby była to powierzchnia malowidła ściennego - efekt chropowatego tynku. Czasami, gdy została dodatkowo przeszlifowywana, daje efekt gładkiej ściany. Przeprowadzone na części obrazów badania spoiw warstwy malarskiej wykazały, iż w większości analizowanych przypadków spoiwem jest olej ${ }^{33}$, ale też dość często identyfikowano temperę ${ }^{34}$.

W sposobie opracowania malarskiego obrazów Muter nie ma schematów. Struktura warstw barwnych jest zróżnicowana zarówno w poszczególnych okresach twórczości artystki, jak i w określonych fragmentach konkretnego obrazu. W dojrzałych pracach plama malarska jest drobna i rozwibrowana. W partii twarzy lekko, swobodnie i punktowo kładziona, w partiach np. ubioru, bardziej płaska, niekiedy znacznie szczelniej wypełnia przestrzeń. Uzyskane na palecie barwy artystka nakładała miejscowo plamą, która mieszała się z warstwami spodnimi, jeśli te były niedostatecznie wyschnięte. Jedne partie wykonane są mięsistą gęstą farbą, która niekiedy wprowadzana była w jednej warstwie niekiedy wieloetapowo, wówczas są to kratery i sople różnokolorowej farby. Na wielu obrazach artystki zauważyć można metodę tzw. przecierek, czyli malowania półsuchym pędzlem w taki sposób, że gęsta farba pozostaje jedynie w splotach płótna, pozwalając oddziaływać warstwom spodnim. W wielu przypadkach obrazy powstawały w kilku sesjach, stąd też można zaobserwować wprowadzanie kolorów zarówno mokre w mokre, jak i mokre na suche. Niekiedy te fragmenty zostawały zamalowywane zostawiając prześwitujące obszary, dodatkowo migocących barw. W obrębie tych fragmentów warstwa malarska jest chropowata i szorstka. Artystka uzyskała ją poprzez nawarstwienie coraz grubszych impastów, prawdopodobnie odsączonej dodatkowo farby. W wielu obrazach poza pędzlem zauważamy użycie szpachelki w nanoszeniu warstw barwnych, jak też użycie odwrotnej strony pędzla.

Często w obrazach Muter barwa podobrazia i jego faktura ma udział w kolorystyce i ostatecznym odbiorze estetycznym obrazu. Taką sytuację obserwujemy m.in. w Portrecie Leopolda Staffa, gdzie artystka wykorzystała podłoże tekturowe, jego ciepły ton, jako jeden ze składników budujących strukturę barwną dzieła, gdzie gładka powierzchnia i kolor podobrazia tekturowego jedynie przeklejonego, bez warstwy zaprawy

cynkowej, innym razem kredy, bieli tytanowej i prawdopodobnie litoponu, w innych przypadkach wypełniacz może stanowić mieszanina węglanu wapnia otrzymanego sztucznie, bieli cynkowej i białego bolusu.

${ }^{33}$ Głównie lniany, niekiedy modyfikowany dodatkiem oleju makowego, lub sam makowy. Przykład mogą stanowić obrazy: Brzozy, gdzie w warstwie malarskiej zidentyfikowano olej lniany z niewielką ilością oleju makowego, Portret pani Lefebvre, gdzie spoiwo warstwy malarskiej stanowi mieszanina oleju makowego i lnianego, oraz Portret Leopolda Staffa, gdzie w partii tła użyto oleju lnianego, natomiast twarz poety o miękko budowanej formie i wyróżniającej się delikatnej fakturze namalowana została, mokre w mokre, z zastosowaniem oleju makowego, z niewielkim dodatkiem oleju lnianego. Olej makowy, który był zalecany do stosowania właśnie w jasnych partiach obrazu, gdyż żółknie mniej niż olej lniany, artystka z pewnością użyła świadomie. Prawdopodobnie zastosowała go w partii karnacji ze względu na jego jeszcze inną właściwość - farby na oleju makowym, impasty lub pół kryjące, można bez obawy przez dłuższy czas, sześć, osiem dni, nakładać wilgotne w wilgotne.

${ }^{34}$ Czego przykładem są między innymi obrazy: Autoportret $w$ turbanie I, który artystka namalowała tłustą temperą na zaprawie kazeinowej, czy Pietà — kompozycja, namalowany temperą kazeinową na zaprawie olejnokazeinowej. 
W sposób zdecydowany wpływa na charakter i estetykę obrazu. W partii tła kładzione laserunkowo oszczędnie i płasko plamy barwne, miejscami w dwu i trzech warstwach stworzyły gładką i błyszczącą materię malarską, uzyskaną dzięki wprowadzeniu znacznej ilości spoiwa z pigmentem o wyszukanych zestawieniach kolorystycznych głębokich zieleni, brązów oraz czerni, nadając całości ciemny koloryt. Sylwetka poety, szybki szkic postaci, sugestywny, wrażeniowy w przestrzeni tła zarysowany czarną energiczną kreską, wypełnioną półprzezroczystą plamą barwną w brązowym tonie (il. 30). Z kolei w portrecie Chany Orloff, podobrazie papierowe, jedynie przeklejone, artystka traktuje podobnie jak w malarstwie akwarelowym, wykorzystując jego kolor jako kolor tła i do którego niejako „dopasowuje” kolorystykę barwną całego przedstawienia ${ }^{35}$. Taką sytuację obserwujemy niemal przez całą twórczość artystki, również na podobraziach płóciennych, gdzie zarówno kolor i faktura płótna, jak i warstwa zaprawy, przemycone przez artystkę między plamami koloru farby budowały ostateczny efekt kolorystyczny i fakturalny danego przedstawienia. Np. w Portrecie oficera czotgisty, biel w partii kołnierzyka z prawej strony to nic innego jak zaprawa, tutaj lekko przeszlifowana. Z kolei w bardzo interesującym znacznych rozmiarów obrazie Dachy w Ondarroa, faktura i kolor płótna oraz oszczędnie, fragmentami założona zaprawa i na niej warstwa malarska, nie wypełniają szczelnie całej powierzchni podobrazia, gdzie między formami barwnymi pozostawione zostały znaczne przestrzenie nie zagruntowanego surowego płótna, które nadają całemu przedstawieniu lekkości i świeżości.

$\mathrm{Na}$ zaprezentowanych przykładach wyłania się nam obraz rozwoju twórczego $\mathrm{Mu}$ ter, gdy w ślad za zmianą formalną idzie zmiana techniki malowania — sposób kładzenia farby, wielkość plam barwnych, ich dobór i nasycenie. Z biegiem lat powierzchnia obrazów Muter, z gładkiej, ulega rozbudowaniu w swej strukturze, a kolorystyka z ciemnej, brązowo-zielonej tonacji ulega znacznemu rozjaśnieniu. Paleta operuje śmiałymi zestawieniami barwnymi, a plama kładziona jest nonszalancko, ekspresyjnie, ale jednak precyzyjnie na powierzchnię zagruntowanego mniej lub bardziej „,szczelnie” i gładko podobrazia. Dojrzała artystycznie Muter maluje obrazy na emulsyjnych gruntach kazeinowych i wapiennych, bardziej chudo i coraz mniej dźwięcznymi kolorami. Powierzchnia obrazów z warstwą zaprawy jest zdecydowanie matowa, nie werniksowana. Brak werniksów na powierzchni obrazów jest zabiegiem celowym, powodującym charakterystyczne stłumienie tonów barw. Na niektórych obrazach poprzez osłabienie nasycenia głębi kolorów efekt wizualny obrazu olejnego na zaprawie kazeinowej zbliżony był do tempery lub malarstwa freskowego, celowo i świadomie osiągnięty. Matowość powierzchni, zastosowanie chłonnych i półchłonnych gruntów stanowią immanentną część ich świadomie budowanej estetyki, są również świadectwem znajomości technik malarskich i warsztatu starych mistrzów, a także warsztatu artystów wówczas awangardowych, będących nie bez wpływu na twórczość artystki, jak wymieniani już Cézanne, Renoir, van Gogh, Gauguin, neoimpresjoniści, którzy sami przygotowywali i przeklejali swoje podobrazia ${ }^{36}$. Technika, jaką operowała Muter, wyrosła również i z ich spuścizny, gdzie artyści ci już w XIX wieku wykorzystywali chude grunty emulsyjne.

Wydawać by się również mogło, że twórczość Meli Muter, zwłaszcza tę dojrzałą, cechuje niekiedy brak dbałości o jakość używanych materiałów, gdzie na dalszy plan

${ }^{35}$ K. A. Cybulska, Mela Muter's Paintings on Cardboard - Preliminary Analysis, [w:] Interdisciplinary Research on the Works of Art, red. J. Olszewska-Świetlik, J. M. Arszyńska, B. Szmelter-Fausek, Torun 2012, s. 273-288.

${ }^{36}$ A. Callen, The Art of Impressionism. Painting Technique and the Making of Modernity, New Haven 2000, s. 51-52. 
schodzi przestrzeganie reguł technologii i technik malarskich. Co obserwujemy w wykorzystywaniu wydawałoby się nie najlepszych, przypadkowych podobrazi, szybko i niestarannie przygotowanych, szczególnie w latach 40. i później. Czy świadome wykorzystywanie tego samego podobrazia z obu jego stron. Czy choćby przykład wspomnianych autorskich przekształceń obrazów, polegających na zmniejszaniu formatów, wprowadzaniu zmian w kompozycji oraz przemalowań wykonywanych po latach na wcześniejszych swoich przedstawieniach, często z odwrotnym skutkiem ${ }^{37}$. Ta sytuacja to efekt prawdopodobnie ciężkiej sytuacji finansowej, która utrzymała się aż do jej śmierci w 1967 roku, w jakiej znalazła się artystka podczas drugiej wojny światowej.

Wiele prac Meli Muter nosi znamię jakby nieskończonych — ,puszczonych”, o podobnym efekcie jak w akwareli, gdzie istotne jest pierwsze wrażenie, jego rejestracja, szybka reakcja na walor i formę. Tę wrażeniowość i ekspresję artystka przenosi również na płótno, gdzie efekt ów wzbogaca dodatkowo o fakturę. Niejednokrotnie pozostawia obrazy niedokończone, $\mathrm{z}$ dużymi fragmentami niezamalowanego kompozycyjnie podobrazia. Co z pewnością jest wynikiem poszukiwania właściwych środków wyrazu, temperamentu artystki, ale również celem samym w sobie. Szczególnie jest to widoczne w pejzażach, ale także portretach i kompozycjach figuralnych, które buduje podobnie jak w malarstwie akwarelowym, tylko wykorzystując inne środki techniczne.

W 1965 roku Muter, która już od jakiegoś czasu nie pracowała z powodu choroby oczu - katarakty, poddała się operacji. Po odzyskaniu wzroku, zaczęła na nowo poprawiać swoje dawne obrazy, przemalowując je częściowo lub całkowicie. Podpisywała również swoje wcześniejsze prace, pierwotnie będące bez sygnatur ${ }^{38}$. Wówczas też namalowała jeden ze swoich ostatnich obrazów - Portret dr Bolesława Nawrockiego ${ }^{39}$ (il. 29). I mimo iż była już osiemdziesięciodziewięcioletnią starszą panią, portret ten jest ostatnim ,akordem” jej wielkiego talentu, wrażliwości na kolor, posiada nadal precyzyjną kreskę oraz typową dla Muter interesującą fakturę i plamę barwną.

Podsumowując twórczość Muter w kontekście jej warsztatu artystycznego, nie można nie odnieść wrażenia, że rozpatrywanie efektu końcowego w analizowanym malarstwie musi mieć swoje odniesienie do odpowiedniej interpretacji techniki i użytych materiałów, zwłaszcza jeśli ów efekt w dużej mierze od nich zależy, a tak właśnie jest w przypadku omawianej twórczości, gdzie w sposób oczywisty widać iż efekty końcowe uzależnione są i wręcz zdeterminowane sposobem przygotowania wszystkich warstw składających się na budowę dzieła malarskiego. Analiza budowy technicznej obrazów autorstwa Meli Muter, malarstwa przecież dwudziestowiecznego, mimo iż

${ }^{37}$ Obrazem, który może posłużyć za przykład zmiany koncepcji artystycznej jest pierwotnie dość dużych rozmiarów obraz Melancholia - Autoportret, przedstawiający siedzącą z profilu w ciemnej sukni i w kapeluszu, młodziutką artystkę. Po autorskiej korekcie formatu, obecny wymiar obrazu wynosi $26 \times 38 \mathrm{~cm}$, ograniczając się jedynie do przedstawienia samej głowy malarki. Archiwalne zdjęcie obrazu sprzed zmiany formatu, znajduje się w archiwum Bolesława i Liny Nawrockich.

${ }^{38}$ Pomysł poprawiania swoich obrazów powstałych niemal przed pół wiekiem, wywołał konflikt między artystką a B. Nawrockim, który usiłował ją przekonać, że nie jest to właściwe $\mathrm{i}$ by tego nie robiła, gdyż niektóre $\mathrm{z}$ prac wymagają raczej gruntownej konserwacji, niż autorskich „,korekt”. Niestety bez rezultatu; patrz: B. Nawrocki, Mela Muter — garść wspomnień, [w:] Mela Muter (1876-1967), s. 8; tenże, Kalendarium, s. 15.

${ }^{39}$ Do jego wykonania jako podłoża użyła odwrocie innego dzieła - Słoneczniki w wazonie z pejzażem $w$ tle, datowanego na lata 1940-1950. 
powszechnie uważanego za świadectwo odejścia od tradycyjnego warsztatu i znajomości technologii malarskiej, jest przykładem, gdzie obraz, na który składa się podobrazie, jego przygotowanie oraz warstwy barwne, to złożony, żmudny proces - świadomy zabieg artysty. A sama twórczość Muter to zapis jej zmagań, nie z materią malarską, bo ta się jej poddaje, ale ze sposobem wypowiedzi artystycznej, ostatecznym wyrazem - samej koncepcji, ale nie formalnej, a koncepcji możliwości technicznych, najbardziej zasadnego dla niej wyboru techniki, która jest jednocześnie zmaganiem się z prawdą o rzeczywistości, którą przedstawia, o świecie, w którym przyszło jej żyć, o emocjach, które nią i jej modelami targają.

Sztuka i malarstwo były dla Meli Muter treścią życia, ale także zawodem i jako zawodowa artystka uprawiała je tak, jak powinno się uprawiać swój zawód, z wielką pasją, której była skłonna podporządkować wszystko i podporządkowała wszystko. To one pomogły zmierzyć się jej z otaczającą ją rzeczywistością, utratą najbliższych, z ludzką nędzą, samotnością, wreszcie starością. A technika Meli Muter jest jej najbardziej wymiernym i trafnym sposobem wypowiedzi artystycznej, wręcz manifestacją ważności podejmowanych przez nią tematów, ma niewątpliwie swoje źródło w znajomości technologii i technik malarskich i w świadomym nimi eksperymentowaniu, a co za tym idzie, także w twórczym czerpaniu ze współczesnych artystce kierunków i nurtów.

Przytoczone przykłady nie stanowią jeszcze pełnej charakterystyki warsztatu artystki, ale odsłaniają po części jego tajniki i możliwości, porządkując wiedzę na temat tak charakterystycznego warsztatu malarskiego. A zgromadzone dane mogą stanowić wyjście dla przyszłych badań i analiz twórczości samej Muter, jak również dla badań nad malarstwem École de Paris i malarstwem dwudziestowiecznym w ogóle.

\section{THE ROLE OF TECHNICAL STRUCTURE AND IDENTIFICATION OF ARTIST'S TECHNIQUE ON THE BASIS OF MELA MUTER'S CREATIVITY}

The research of the technical structure of art works aim towards answering basic questions: what materials are used, what is their quality, in what quantity and how they are used. On how many original (technological) layers does the structure of work of art, how thick and of what composition are they. Apart from materials used in the process of art creation, materials added during conservation or reparation, so called secondary elements, are also a subject to research. It is important to determine what influence they have on the final perception of the work, and to what extent they may falsify or tamper with it. The information on the painting's structure does not always directly influence the interpretation of its humanistic character, however it does have a crucial meaning in explaining what means were used in order to obtain a concrete artistic expression of the work of art. Moreover, it allows to understand how the individual elements, sometimes of little importance as it may seem, co-create its complicated nature and by what technological process accompanies it.

KEY WORDS: technical structure research; artist's workshop; technology of painting. 